\title{
The role of high carbohydrate-rich food intake and severity of wheezing exacerbation in children between 2 to 6 years aged.
}

\author{
Jefferson Buendia ${ }^{1}$, Ranniery Acuña-Cordero ${ }^{2}$, and HERNAN TALAMONI ${ }^{3}$ \\ ${ }^{1}$ University of Antioquia \\ ${ }^{2}$ Hospital Militar Central \\ ${ }^{3}$ Instituto Universitario Escuela de Medicina del Hospital Italiano de Buenos Aires
}

July 4, 2021

\begin{abstract}
Introduction. Dietary habits in developing countries are characterized in the last decades by low intake of fruits, vegetables, and high consumption of sweetened drinks. Most of the evidence linking carbohydrate intake and asthma comes from children over 6 years of age. The aim of this study was to examine the association of macronutrient intake with the severity of wheezing exacerbation in children aged 2 to 6 years Methods. We performed a prospective cohort study that included all children aged 2 to 6 years hospitalized by a wheezing exacerbation in two tertiary centers in Rionegro, Colombia. Dietary data were collected using a food frequency questionnaire (FFQ) validated in the Colombian population. Gina classification of acute wheezing in children 5 years and younger was to define the severity of the wheezing Results During the study period, 228 cases of patients with wheezing exacerbation were included. Wheezing severity was dose-dependently associated with protein and carbohydrate-rich intake. The variables included in the multivariable analysis included reactive C protein, smoking at home, atopic dermatitis, protein, and carbohydrate-rich food intake Conclusion High carbohydrate-rich food intake was associated with severity of wheezing exacerbation adjusted by other known risk factors such as atopic, smoking, and reactive $\mathrm{C}$ protein. Also, we found a negative association of severity of wheezing exacerbation with high protein-rich food intake adjusted by the factors mentioned above. This evidence should motivate the development of public health policies to control the consumption of sugar-rich products in children under 6 years of age.
\end{abstract}

\section{Hosted file}

MAIN DOCUMENT 280621.docx available at https://authorea.com/users/316889/articles/528914the-role-of-high-carbohydrate-rich-food-intake-and-severity-of-wheezing-exacerbation-inchildren-between-2-to-6-years-aged

\section{Hosted file}

Table 1 (1).docx available at https://authorea.com/users/316889/articles/528914-the-roleof-high-carbohydrate-rich-food-intake-and-severity-of-wheezing-exacerbation-in-childrenbetween-2-to-6-years-aged

\section{Hosted file}

Table 2.docx available at https://authorea.com/users/316889/articles/528914-the-role-ofhigh-carbohydrate-rich-food-intake-and-severity-of-wheezing-exacerbation-in-childrenbetween-2-to-6-years-aged 

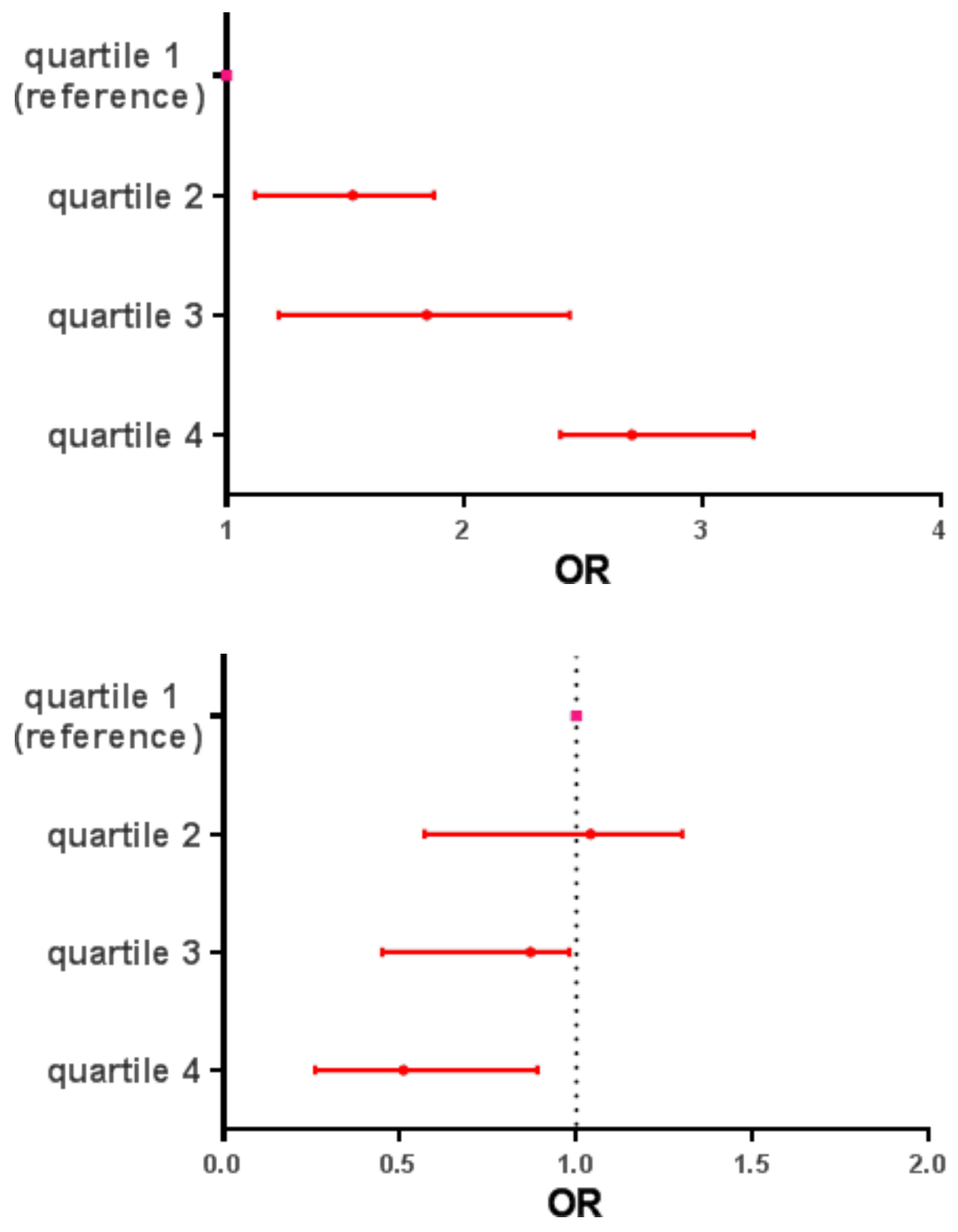